\title{
BIOMONITORING DAMPAK EKOLOGIS MERKURI DI DAERAH ALIRAN SUNGAI TORAUT KABUPATEN BOLAANG MONGONDOW
}

\author{
BIOMONITORING ECOLOGICAL IMPACTS MERKURI IN TORAUT WATERSHED \\ BOLAANG MONGONDOW DISTRICT
}

\author{
John L. Rantung dan Sofia Wantasen*) \\ "Fakultas Pertanian Universitas Sam Ratulangi Manado \\ email: rantung_john@yahoo.com;swantasen@yahoo.co.id
}

\begin{abstract}
Traditional gold mining in Toraut Watershed Bolaang Mongondow District was used Merkuri Amalgamation that produced tailing. Tailing are discharged to river and environment sorounding that can enter Toraut River and flows to the down stream Mongondow river (beach Inobonto). This study aims: 1) To determine $\mathrm{Hg}$ concentrations in River Toraut up stream, middle stream and down stream; 2) To determine $\mathrm{Hg}$ concentrations in sediment of the River Toraut up stream, middle stream and down stream; 3) To determine $\mathrm{Hg}$ concentrations in aquatic plantsof the River Toraut up stream, middle stream and down stream. Location research in River Toraut up stream, middle stream and down stream. Data collected by observation and laboratory analysis Merkuri concentration in River Toraut, sediment, and aquatic plant. Method data analysis are descriptif, Graphic Method and to compare with standart Goverment PP. No.82/2001 Class II. The analysis showed that the concentration of Merkuri in River Toraut up stream, in the middle stream and down stream is $<0.00005 \mathrm{mg} / \mathrm{l}$. The concentration of Merkuri in sediments River Toraut up stream, the middle stream and down stream ranged $<0.05-1.45$ $\mathrm{mg} / \mathrm{kg}$ dry. The concentration of Merkuri in tissue plant aquatic location up stream of the River Toraut, the middle stream and down stream range $<0.001-0.013 \mathrm{mg} / \mathrm{kg}$ wet .
\end{abstract}

Keywords : biomonitoring, ecological impacts merkuri, Toraut Watershed

\begin{abstract}
ABSTRAK
Pengolahan emas secara tradisional di Daerah Aliran Sungai (DAS) Toraut menggunakan Merkuri $(\mathrm{Hg})$ dalam proses amalgamasi menghasilkan limbah. Limbah pengolahan tersebut dibuang ke sungai dan lingkungan sekitar dapat masuk ke Sungai Toraut dan mengalir sampai ke Sungai Mongondow hilir serta bermuara di laut. Penelitian ini bertujuan untuk mengetahui: 1) Konsentrasi Merkuri (Hg) di air Sungai Toraut bagian hulu, tengah dan hilir; 2) Konsentrasi Merkuri $(\mathrm{Hg})$ di sedimen Sungai Toraut bagian hulu, tengah dan hilir; 3) Konsentrasi Merkuri $(\mathrm{Hg})$ di tanaman air yang terdapat di Sungai Toraut bagian hulu, tengah dan hilir. Lokasi penelitian adalah Sungai Toraut bagian hulu, tengah dan hilir.Cara penelitianadalah observasi lapang dan analisis laboratorium konsentrasi merkuri yang terdapat di air Sungai Toraut, sedimen dan tanaman air. Metode analisis secara deskriptif, tabelaris dan membandingkan dengan standar baku mutu PP No.82/2001 Kelas II. Hasil analisis menunjukkan bahwa Konsentrasi Merkuri di Sungai Toraut bagian hulu, bagian tengah dan bagian hilir adalah<0,00005 mg/l. Konsentrasi Merkuri di sedimen Sungai Toraut bagian hulu, bagian tengah dan bagian hilir berkisar antara $<0,05-1,45 \mathrm{mg} / \mathrm{kg}$ dry. Konsentrasi merkuri di jaringan tanaman air lokasi Sungai Toraut bagian hulu, bagian tengah dan bagian hilir berkisar antara $<0,001-0,013 \mathrm{mg} / \mathrm{kg}$ wet.

Kata kunci: biomonitoring, dampak ekologis merkuri, DAS Toraut
\end{abstract}




\section{PENDAHULUAN}

Aktivitas pertambangan emas terutama yang menggunakan merkuri dalam proses amalgamasi dapat menyebabkan pencemaran logam berat merkuri pada air, sedimen, dan tumbuhan air. Logam berat masuk ke ekosistem perairan akan menurunkan nilai guna ekosistem perairan untuk air minum, budidaya ikan, tumbuhan air, rekreasi dan lain-lain sehingga mahluk hidup dari perairan tersebut seperti tumbuhan/tanaman air yang mengandung logam berat bila dikonsumsi manusia dapat membahayakan kesehatan manusia itu sendiri. Merkuri yang diperbolehkan berada di air sungai sesuai Peraturan Pemerintah Nomor 82 Tahun 2001 adalah 0,002 mg/l (KLH, 2001). Merkuri yang diperbolehkan berada di sedimen (Dutch Quality Standards for Metals in sediment (IADC/CEDA, 1997 yaitu konsentrasi 0,3-1,3 mg/ kg dry).

Pertambangan emas di DAS Toraut telah beroperasi sejak tahun delapan puluhan oleh sekelompok masyarakat lokal melakukan aktivitas penambangan emas rakyat menggunakan merkuri dalam proses amalgamasi. Buangan limbah penambangan emas hasil proses amalgamasi ke badan air (sungai) tanpa melalui proses pengolahan terlebih dahulu, akan mengakibatkan pencemaran di badan air/sungai dan perairan laut. Pembuangan limbah tersebut secara terus menerus bukan saja dapat mencemari air, tetapi juga menyebabkan terakumulasinya logam berat $\mathrm{Hg}$ dalam sedimen sehingga ekosistem perairan akan rusak. Sumber hayati di darat dan dalam rantai makanan manusia sebagai konsumen hasil sumber daya hayati akan menerima dampak negatifnya.

Secara umum akumulasi logam terjadi di permukaan daun, batang, dan akar tanaman (Connell dan Miller, 1995). Menurut Priyanto dan Prayitno (2007), logam berat dalam media dengan cepat diserap oleh tanaman, walaupun berada pada konsentrasi yang sangat rendah. Logam merkuri $(\mathrm{Hg})$ masuk ke dalam tubuh manusia secara tidak langsung yaitu dengan memakan bahan pangan baik hewan maupun tumbuhan yang telah terkontaminasi oleh Merkuri (Levander dan Cheng, 1980). Pengaruh dari logam Merkuri terhadap ling- kungan tergantung kepada toksisitas Merkuri tersebut. Senyawa-senyawa Merkuri yang berbeda mempunyai sifat toksisitas, distribusi, akumulasi dan waktu retensi dalam tubuh yang berbeda-beda. Transformasi hayati dari senyawa Merkuri yang satu ke senyawa Merkuri yang lain dapat terjadi baik dalam lingkungan maupun dalam tubuh.

Senyawa-senyawa $\mathrm{Hg}$ organik jauh lebih toksik dibandingkan bentuk anorganik. Di lingkungan perairan, raksa anorganik diubah oleh mikro organisme menjadi metil raksa yang mempunyai konsentrasi racun lebih tinggi dan lebih mudah diserap jaringan, kurang lebih $95 \%$ metil raksa diserap oleh usus, sebagian besar disimpan dalam tubuh dan kurang dari 1\% yang dibuang (Mason, 1991).

Mekanisme penyerapan Merkuri dalam jaringan melalui proses transformasi biologis (biotransformasi), logam berat yang terakumulasi dalam tubuh organisme hidup (bioakumulasi), kemudian terjadi peningkatan konsentrasi logam berat pada tingkat pemangsa yang lebih tinggi yang disebut magnifikasi biologis (biomagnifikasi). Secara tidak langsung proses biomagnifikasi dapat terjadi dalam jaringan tubuh manusia yang memakan hasil perikanan atau pertanian yang tercemar oleh logam berat Merkuri dalam lingkungan perairan. Akhirnya manusia yang menempati posisi puncak dari semua sistem rantai makanan akan mengkonsumsi Merkuri dalam jumlah yang cukup besar (lebih besar dari organisme hidup lainnya (Taftazani, 2007). Hasil penelitian Wilken dan Hintelmann (1991) dalam Suheryanto, dkk (2013), bahwa kadar logam berat dalam sedimen lebih tinggi dibandingkan dalam air. Tingginya konsentrasi Merkuri di sedimen merupakan indikasi pencemaran telah terjadi (Susintowati dan Hadisusanto, 2014).

\section{METODE PENELITIAN}

Penelitian dilakukan di DAS Toraut yaitu determinasi konsentrasi Merkuri di Sungai Toraut; Sedimen; Jaringan Tanaman Air. Waktu pengambilan sampel dilakukan pada Bulan Agustus sampai dengan September 2014. Lokasi pengambilan 
sampel pada ketiga lokasi tersebut diuraikan sebagai berikut :

\section{Konsentrasi Logam Merkuri di Sungai Toraut}

Pengambilan sampel air sungai dilakukan pada 3 (tiga) lokasi yaitu Sungai Toraut bagian hulu, bagian tengah dan bagian hilir. Pengambilan sampel air dilakukan secara composite dengan menggunakan water sampler (Hadi, 2015). Sampel air untuk pengukuran total Merkuri disaring terlebih dahulu dengan kertas saring yang berpori $0,45 \mu \mathrm{m}$, kemudian dimasukkan dalam botol sampel dan diawetkan langsung dengan larutan $\mathrm{HNO}_{3}$. Sampel air dimasukkan dalam cool boxdan dibawa ke laboratorium.

\section{Konsentrasi Logam Merkuri di Sedimen}

Pengambilan sampel sedimen dilakukan pada 3 (tiga) lokasi yaitu bagian hulu, bagian tengah dan bagian hilir. Lokasi pengambilan sampel sedimen sama seperti untuk pengambilan sampel kualitas air di Sungai Toraut. Pada setiap stasiun, areal sedimen yang tersampel berkisar 0,05 $\mathrm{m}^{2}$ dengan kedalaman sedimen sekitar $5-10 \mathrm{~cm}$. Sampel sedimen dimasukkan kedalam kantong plastik dan disimpan dalam cool box dan dibawa ke laboratorium.

\section{Konsentrasi Logam Merkuri di Jaringan Tanaman}

Sebagai indikator penyerapan logam berat ke jaringan (tissue) maka dilakukan pengambilan sampel jaringan tanaman yang terdapat di Sungai Toraut. Sampel tanaman tersebut dimasukkan dalam kantong plastik dan dimasukkan dalam cool box dan dibawa ke laboratorium.

\section{Analisis Logam Berat}

Analisis total merkuri dilakukan di Laboratorium. Untuk kandungan logam dalam air, dilakukan dengan menggunakan prosedur Standard Methods for Examination of Water and Wastewater 20th Edition 1998. Instrumen analisis menggunakan Inductively Coupled Plasma Spectrometry (ICPMS) sesuai rekomendasi (EPA 7000 series). Untuk mengetahui logam di sedimen, analisis dilakukan berdasarkan prosedur Test Methods for Evaluating Solid Waste SW-846 Method 3050B yang direkomendasikan oleh USEPA. Sampel di analisis dengan Cold Vapour Atomic Absorption Spectrophotometry (EPA Method 7470/7471A). SNI 066992.2-2004 dan SNI 7387: 2009. ICS 67.220.20 (Anonimus, 2009). Pada jaringan tumbuhan, analisis untuk kandungan logam berat dilakukan dengan prosedur Recommended Guidelines for Measuring Metals in Puged Sound Marine Water, Sediment, and Tissue Sample. Alat instrument analisis dengan Atomic Absorption Spectrophotometry (EPA Method 7000 series).

\section{Analisis Data}

Metode analisis data secara deskriptif, tabelaris dan membandingkan dengan standar baku mutu PP No. 82/2001 Kelas II (KLH, 2001), dan Dutch Quality Standards for Metals in sediment (IADC/CEDA, 1997).

\section{HASIL DAN PEMBAHASAN}

\section{Konsentrasi Logam Merkuri di Sungai Toraut}

Pengukuran konsentrasi logam Merkuri di Sungai Toraut dilakukan dengan mengambil sampel air pada 3 (tiga) lokasi yaitu Sungai Toraut bagian hulu, bagian tengah dan bagian hilir. Hasil analisis konsentrasi Merkuri di Sungai Toraut disajikan pada Tabel 1.

Tabel 1. Konsentrasi Logam Merkuri $(\mathrm{Hg})$ di Sungai Toraut

(Table 1. Concentration of Mercury $(\mathrm{Hg})$ in the River Toraut)

\begin{tabular}{|c|c|c|c|c|c|}
\hline No & Parameter & Satuan & \multicolumn{3}{|c|}{ Sungai Toraut } \\
\hline & Kimia & & Hulu & Tengah & Muara \\
\hline 1. & Merkuri $(\mathrm{Hg})$ & $\mathrm{mg} / \mathrm{l}$ & $<0,00005$ & $<0,00005$ & $<0,00005$ \\
\hline Baku & u PP No. 82 tahun 2001 Kelas II & $\mathrm{mg} / \mathrm{l}$ & 0,002 & 0,002 & 0,002 \\
\hline
\end{tabular}

Sumber: Rantung \& Wantasen, 2014 
Hasil analisis sampel air pada 3 (tiga) lokasi tersebut menunjukkan bahwa konsentrasi Merkuri $(\mathrm{Hg})$ di Sungai Toraut Hulu, Tengah, dan Muara adalah $<0,00005 \mathrm{mg} / \mathrm{l}$. Konsentrasi tersebut memenuhi baku mutu sesuai PP No. 82 tahun 2001 Kelas II konsentrasi Merkuri $(\mathrm{Hg})$ di air permukaan adalah 0,002 mg/l (Keterangan: Kelas dua, air yang peruntukannya dapat digunakan untuk prasarana/ sarana rekreasi air, pembudidayaan ikan air tawar, peternakan, air untuk mengairi pertanaman, dan atau peruntukkan lain yang mempersyaratkan mutu air yang sama dengan kegunaan tersebut.

\section{Konsentrasi Logam Merkuri di Sedimen}

Pengukuran konsentrasi logam Merkuri di sedimen dilakukan dengan mengambil sampel air pada 3 (tiga) lokasi yaitu sedimen di Sungai Toraut bagian hulu, bagian tengah dan bagian hilir. Hasil analisis konsentrasi merkuri di sedimen Sungai Toraut disajikan pada Tabel 2.

Hasil analisis sampel sedimen pada 3 (tiga) lokasi menunjukkan bahwa konsentrasi Merkuri (Hg) di sedimen Sungai Toraut bagian Hulu
0,89 mg/ kg dry; Sungai Toraut bagian Tengah 1,45 $\mathrm{mg} / \mathrm{kg}$ dry, Sungai Toraut bagian Muara $<0,05 \mathrm{mg} /$ $\mathrm{kg}$ dry. Peraturan di Republik Indonesia belum mengatur Baku mutu konsentrasi Merkuri $(\mathrm{Hg})$ yang diperbolehkan berada di sedimen. Untuk itu baku mutu yang digunakan adalah Dutch Quality Standards for Metals in sediment (IADC/CEDA, 1997): konsentrasi 0,3- 1,3 mg/ kg dry. Dengan demikian data pada Tabel 2 menunjukkan bahwa konsentrasi Merkuri $(\mathrm{Hg})$ di sedimen Sungai Toraut bagian hulu, dan Sungai Toraut bagian Tengah telah melebihi batas bawah baku mutu yaitu 0,3$1,3 \mathrm{mg} / \mathrm{kg}$ dry. Konsentrasi Merkuri $(\mathrm{Hg}) \mathrm{di}$ sedimen Sungai Toraut bagian tengah $1,45 \mathrm{mg} / \mathrm{kg}$ dry, telah melebihi batas bawah baku mutu yaitu $0,3 \mathrm{mg} / \mathrm{kg}$ dry- $1,3 \mathrm{mg} / \mathrm{kg}$ dry. Konsentrasi Merkuri di Sungai Toraut hilir $<0,05 \mathrm{mg} / \mathrm{kg}$ dry adalah lebih kecil dari Dutch Quality Standards for Metals in sediment (IADC/CEDA, 1997) yaitu konsentrasi 0,3$1,3 \mathrm{mg} / \mathrm{kg}$ dry. Konsentrasi Merkuri( $\mathrm{Hg})$ di sedimen digambarkan dalam bentuk grafik (Gambar 1).

Tabel 2. Konsentrasi Logam Merkuri $(\mathrm{Hg})$ di Sedimen Sungai Toraut

(Table 2. Concentration of Mercury $(\mathrm{Hg})$ in the River Sediment Toraut)

\begin{tabular}{clcccc}
\multirow{2}{*}{ No. } & \multicolumn{2}{c}{ Parameter } & Satuan & \multicolumn{3}{c}{ Sungai Toraut } \\
\cline { 2 - 6 } & Kimia & & Hulu & Tengah & Muara \\
\hline 1. & Merkuri $(\mathrm{Hg})$ & $\mathrm{mg} / \mathrm{kg}$ dry & 0,89 & 1,45 & $<0,05$ \\
& Total solid & $\%$ & 14 & 9,6 & 17 \\
Dutch & Quality Standards for Metals & in sediment & & $0,3-1,3 \mathrm{mg} / \mathrm{kg}$ dry &
\end{tabular}

Dutch Quality Standards for Metals in sediment (IADC/CEDA, 1997) 0,3-1,3 mg/ kg dry

Sumber: Rantung \& Wantasen, 2014

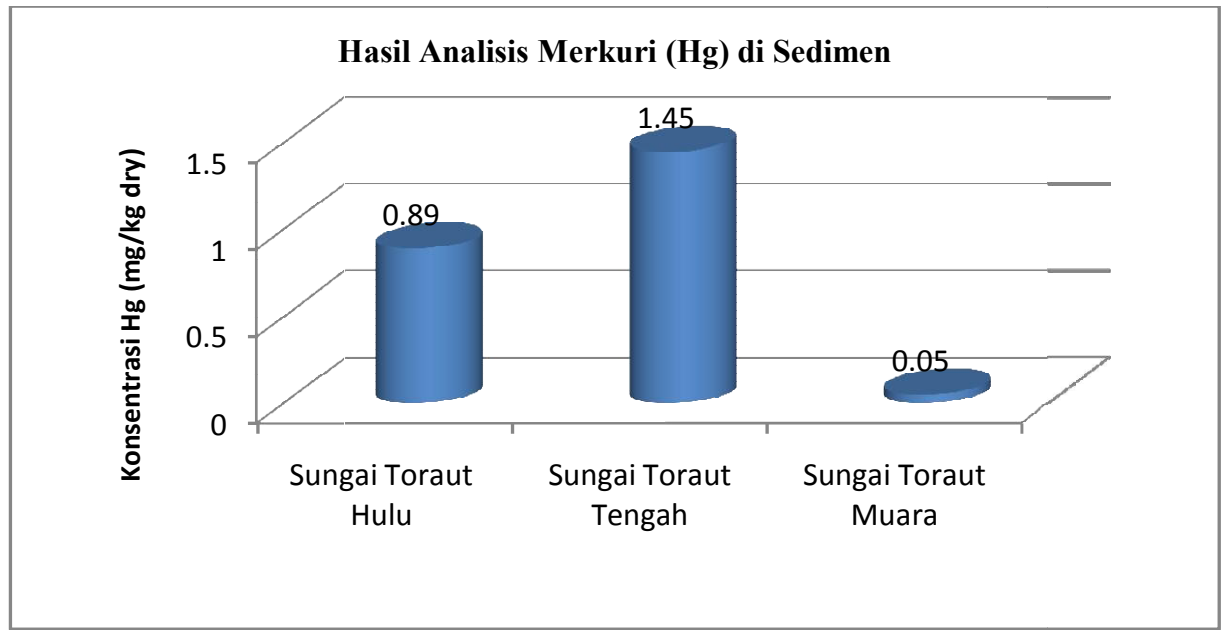

Gambar 1. Konsentrasi Merkuri $(\mathrm{Hg})$ di Sedimen Sungai Toraut

(Figure 1. Concentration of Mercury (Hg) in the River Sediment Toraut) 
Sedimen merupakan bagian penting dalam ekosistem perairan karena merupakan tempat terjadinya siklus biokimia dan merupakan basis jaringjaring makanan. Kandungan bahan organik umumnya terdapat pada sedimen didasari lumpur dibandingkan dengan sedimen dengan tekstur berpasir, hal ini dikarenakan sedimen berlumpur lebih mengikat bahan organik dengan teksturnya yang padat dan cenderung halus, sedangkan tekstur sedimen berpasir cenderung tidak mengikat bahan organik lebih besar karena teksturnya yang kasar dan bersifat terpisah-pisah. Ukuran sedimen mempengaruhi jumlah bahan organik. Merkuri $(\mathrm{Hg})$ secara alami terdapat di alam sangatlah sedikit yaitu Merkuri berasal dari kegiatan gunung berapi, rembesan-rembesan air tanah yang melewati daerah yang mengandung Merkuri. Konsentrasi meningkat setelah manusia mengunakan Merkuri sebagai bahan industri. Selain pengaruh alam, keberadaan Merkuri di lingkungan dapat berasal dari berbagai aktivitas manusia yang menghasilkan limbah Merkuri sehingga konsentrasi Merkuri di lingkungan dapat meningkat seiring dengan kemajuan teknologi dan pertambahan jumlah penduduk (Darmono, 2008).

Konsentrasi Merkuri tertinggi ditemukan pada sampel sedimen di lokasi Sungai Toraut bagian tengah, hal ini disebabkan lokasi bagian tengah terdapat pertemuan sungai yang melintasi tempat penambangan rakyat dan pengolahan bijih emas. Limbah logam Merkuri merupakan hasil samping proses amalgamasi pada pengolahan bijih emas. Konsentrasi Merkuri pada sedimen di lokasi hilir lebih rendah dibandingkan konsentrasi lokasi tengah. Hal ini disebabkan karakteristik aliran Sungai Toraut, dimana aliran air sungai cukup deras dan didukung oleh perbedaan elevasi atau ketinggian permukaan sungai sehingga senyawa material pembentuk sedimen yang ada di daerah tengah yang terkontaminasi oleh logam Merkuri akan hanyut terbawa arus.

\section{Konsentrasi Logam Merkuri di Jaringan Tanaman Kangkung Air (Ipomoea aquatica Forssk)}

Pengukuran konsentrasi logam Merkuri $d$ jaringan tanaman Kangkung Air (Ipomoea aquatica Forssk) dilakukan dengan mengambil sampel air pada 3 (tiga) lokasi yaitu tanaman Kangkung Air di Sungai Toraut bagian hulu, bagian tengah dan bagian hilir. Hasil analisis konsentrasi logam Merkuri di jaringan tanaman Kangkung Air meliputi batang, akar dan daun tersebut disajikan pada Tabel 3.

Hasil analisis jaringan tanaman Kangkung Air pada 3 (tiga) lokasi menunjukkan bahwa konsentrasi Merkuri $(\mathrm{Hg})$ di jaringan tanaman lokasi Sungai Toraut bagian Hulu $0,009 \mathrm{mg} / \mathrm{kg}$ wet; Sungai Toraut bagian Tengah $<0,001 \mathrm{mg} / \mathrm{kg}$ wet, Sungai Toraut bagian hilir $0,013 \mathrm{mg} / \mathrm{kg}$ wet. Peraturan di Republik Indonesia belum mengatur Baku mutu konsentrasi Merkuri $(\mathrm{Hg})$ di jaringan tanaman. Namun mengacu beberapa negara lain misalnya Jepang dan Canada baku mutu konsentrasi $\mathrm{Hg}$ maksimal sebesar 0,3 ppm (Mahmud, dkk., 2014).

Konsentrasi Merkuri $(\mathrm{Hg})$ di jaringan tanaman lokasi Sungai Toraut bagian hulu, Sungai Toraut bagian tengah, Sungai Toraut bagian hilir digambarkan dalam bentuk grafik terdapat pada Gambar 2.

Konsentrasi merkuri tertinggi di jaringan tanaman ditemukan pada sampel jaringan tanaman di lokasi Sungai Toraut bagian hilir $0,013 \mathrm{mg} / \mathrm{kg}$ wet. Hal ini disebabkan karakteristik aliran air sungai cukup deras dan didukung oleh perbedaan elevasi atau ketinggian permukaan sungai sehingga senyawa material pembentuk sedimen yang ada di daerah tengah yang terkontaminasi oleh residu logam Merkuri akan hanyut terbawa arus sampai Sungai Toraut hilir, dimana aliran air sungai di bagian hilir kurang deras dibandingkan dengan arus di bagian hulu dan tengah, kondisi tersebut berpotensi terakumulasinya residu logam Merkuri di jaringan tanaman Kangkung Air. 
Tabel 3. Konsentrasi Logam Merkuri di Jaringan Tanaman Kangkung Air (Ipomoea aquatica Forssk)

Table 3 Metal Mercury Concentration in Plant Tissue Kangkung (Ipomoea aquatica Forssk)

\begin{tabular}{|c|c|c|c|c|c|}
\hline \multirow[t]{2}{*}{ No. } & Parameter & \multirow[t]{2}{*}{ Satuan } & \multicolumn{3}{|c|}{ Sungai Toraut } \\
\hline & KIMIA & & Hulu & Tengah & Muara \\
\hline 1. & Merkuri $(\mathrm{Hg})$ & $\mathrm{mg} / \mathrm{kg}$ wet & 0,009 & $<0,001$ & 0,013 \\
\hline
\end{tabular}

Sumber: Rantung \& Wantasen, 2014

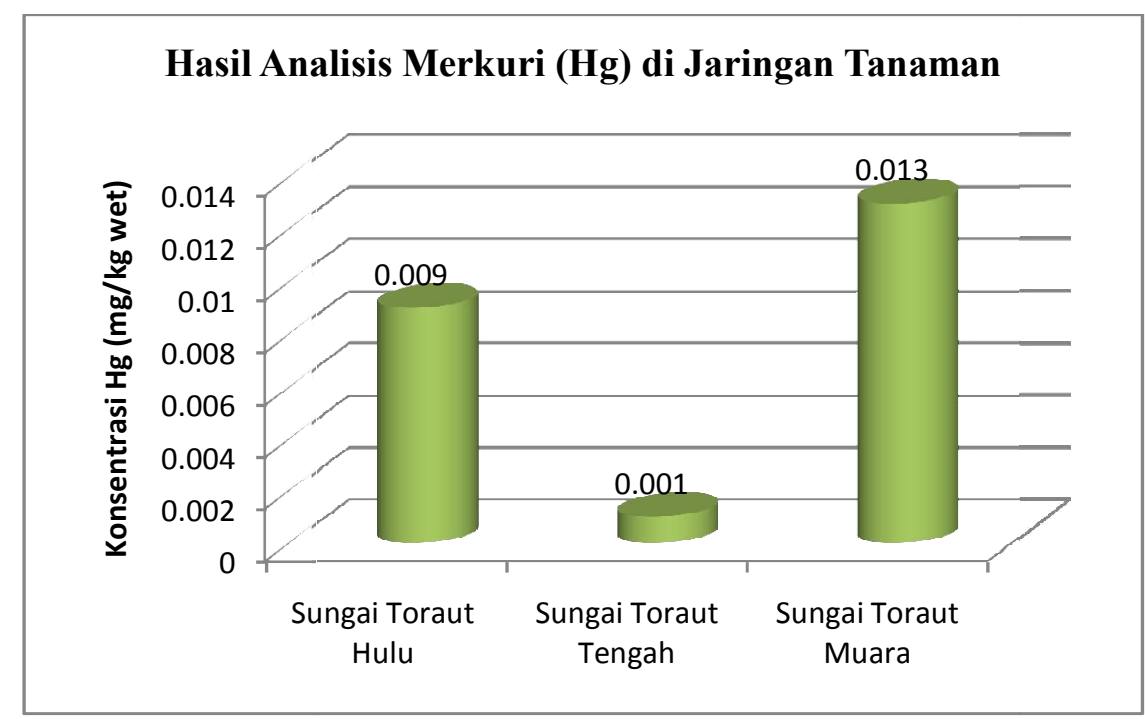

Gambar 2. Konsentrasi Merkuri $(\mathrm{Hg})$ Jaringan Tanaman di Lokasi Sungai Toraut

(Figure 2. Metal Mercury Concentration (Hg) in Plant Tissue Kangkung (Ipomoea aquatica Forssk))

\section{KESIMPULAN}

Konsentrasi Merkuri di Sungai Toraut bagian hulu, bagian tengah dan bagian hilir adalah $<0,00005 \mathrm{mg} /$. Nilai ini masih di bawah ambang batas sesuai Baku Mutu Peraturan Pemerintah Nomor 82 tahun 2001 Kelas II.

Konsentrasi Merkuri di sedimen Sungai Toraut bagian hulu, bagian tengah dan bagian hilir berkisar antara $<0,05-1,45 \mathrm{mg} / \mathrm{kg} d \mathrm{dr}$, melebihi Baku mutu konsentrasi Merkuri $(\mathrm{Hg})$ yang diperbolehkan berada di sedimen (Dutch Quality Standards for Metals in sediment (IADC/CEDA, 1997): konsentrasi 0,3-1,3 mg/ kg dry).

Konsentrasi Merkuri di jaringan tanaman lokasi Sungai Toraut bagian hulu, bagian tengah dan bagian hilir berkisar antara $<0,001-0,013 \mathrm{mg} /$ $\mathrm{kg}$ wet.

\section{UCAPAN TERIMA KASIH}

Penulis mengucapkan terima kasih kepada Ditjen Dikti Kemendiknas atas dukungan dana penelitian Hibah Bersaing Tahun 2014.

\section{DAFTAR PUSTAKA}

Anonimus, 2009. Batas Maksimum Cemaran Logam Berat dalam Pangan. SNI 7387: 2009. ICS 67.220.20 Badan Standarisasi Nasional Jakarta.

Connell, D.W., dan G.J., Miller. 1995. Kimia dan Ekotoksikologi Pencemaran. Universitas Indonesia Press, Jakarta.

Darmono, 2008. Lingkungan Hidup dan Pencemaran, Hubungannya dengan Toksikologi Senyawa Logam. UI Press, Jakarta. 
Hadi, A. 2015. Pengambilan Sampel Lingkungan, Penerbit Erlangga, Jakarta.

KLH. 2001. Peraturan Pemerintah Nomor 82 tahun 2001 tanggal 14 Desember 2001 tentang Pengelolaan Kualitas Air dan Pengendalian PencemaranAir (Kelas II).

Levander, O. A. and L. Cheng. 1980. Micronutrient Interaction: Vitamins, Minerals and Hazardous Elements. Annals of New York Academy of Science. Vol : 355. The New York Academy of Science, New York.

Mahmud, M., F. Lihawa, H. lyabu, dan M. Sakakibara. 2014. Kajian Pencemaran Merkuri Terhadap Lingkungan di Kabupaten Gorontalo Utara. Kerjasama Universitas Negeri Gorontalo dan Ehime University (Dana PNBP Tahun Anggaran 2014), Gorontalo.

Mason, C.F. 1991. Utility Biologyof Freshwater Pollution. Second edition. Longman Group UK Ltd. England.

Priyanto, B dan J. Prayitno. 2007. Fitoremediasi sebagai sebuah Teknologi Pemulihan Pencemaran. Khususnya Logam Berat. It.bppt.tripod
Rantung, J. L. dan S. Wantasen, 2014. Biomonitoring Dampak Ekologi Merkuri Pada Pertambangan Emas Rakyat Dumoga Kabupaten Bolaang Mongondow. Penelitian Hibah Bersaing Tahun ke I.

Suheryanto, Poedji Loekitowaty $\mathrm{H}$, dan Erwin Doyosi. 2013. Kajian Pencemaran Merkuri Total Di Perairan Sungai Rupit Musi Rawas Sumatera Selatan. Prosiding Semirata FMIPA Universitas Lampung. Hal : 385- 391.

Susintowati dan S. Hadisusanto. 2014, Bioakumulasi Merkuri dan Struktur Hepatopankreas pada Terebralia sulcata dan Nerita argus (Mouluska: Gastropoda) di Kawasan Bekas Penggelondongan Emas, Muara Sungai Lampon, Banyuwangi, Jawa Timur, Jurnal Manusia dan Lingkungan Vol. 21 (1): 34-40.

Taftazani, A. 2007. Distribusi Konsentrasi Logam Berat $\mathrm{Hg}$ dan $\mathrm{Cr}$ pada Sampel Lingkungan Perairan Surabaya. Pustek Akselerator dan Proses Bahan-BATAN Yogyakarta, Prosiding PPI-PDIPTN: 3645. 